\title{
ENERGY EFFICIENCY AND ECONOMIC ANALYSIS IN TOMATO PRODUCTION: A CASE STUDY OF MERSIN PROVINCE IN THE MEDITERRANEAN REGION
}

\author{
YELMEN, B. ${ }^{{ }^{*}}-$ ŞAHIN, H. H. ${ }^{2}-$ ÇAKIR, M. T. $^{3}$ \\ ${ }^{1}$ Wastewater Treatment Department, Adana Metropolitan Municipality, 01120 Adana, Turkey \\ ${ }^{2}$ Adana Metropolitan Municipality, 01120 Adana, Turkey \\ ${ }^{3}$ Health Institutes of Turkey (TUSEB), 06590 Ankara, Turkey \\ *Corresponding author \\ e-mail: bekiryelmen@gmail.com
}

(Received 22 $2^{\text {nd }}$ Feb 2019; accepted $3^{\text {rd }}$ May 2019)

\begin{abstract}
This study was carried out to find the energy equivalents of inputs and outputs in tomato cultivation in the Mediterranean region of Mersin province. For this aim, the energy balance between values of the input and output energies per unit field for tomato cultivation in open-field and greenhouses was investigated. Energy efficiency, energy density, energy efficiency were compared in terms of cost-benefit ratio. Data were collected and analyzed in open-field (112) and in greenhouses (14) from producers of tomato cultivation. The results showed that the total energy requirement in open fields and greenhouses was 56127.77 and $245246.78 \mathrm{MJ} \mathrm{ha}^{-1}$, respectively. Energy use efficiency in the open-fields and in greenhouses was realized as 1.12 and 0.75 respectively. The cost-benefit-ratios were 2.32 in open-fields and 3.06 in greenhouses. According to the current results, the open-fields tomato production system has a higher energy efficiency than the greenhouse tomato production system, while the greenhouse system has a higher economic benefit.
\end{abstract}

Keywords: tomato production, greenhouse, energy, energy consumption, cost benefit ratio

\section{Introduction}

Tomato (Lycopersicon esculentum Mill.) is a perennial plant in tropical regions which is Solanales of the family of Solanaceae Lycopersicon family, depending on the singleyear in temperate climates (Kinet and Peet, 1997). In total vegetable production, which is 1.1 billion tons in the world, tomatoes have $15 \%$ ratio with 162 million tons. In Turkey, the share of total vegetable production with production reaching 12.6 million tons exceeded $40 \%$. In the current figures of tomato production; Turkey ranks 4th in the world (FAO, 2013). High adaptability, open the predisposition to greenhouse cultivation next to agriculture, as well as one of the various forms of reasons such as the availability of the processing industry, where most heavily cultivated and most widely consumed and the Mediterranean Basin which Turkey involved in. The amount of tomato consumption per capita in Turkey is $115 \mathrm{~kg} /$ year around (Yanmaz et al., 2015). Regional distribution in the largest ratio, is Mediterranean region with the $31 \%$ of the total (Abak, 2018). Mersin province is one of Turkey's largest tomato growing fields (ha) (Anonymous, 2017). From 2000 to 2015; Turkey's greenhouse fields increased with the ratio of $58.41 \%$, from 47355.5 ha to 75015.5 (Turemiş, 2015). Today agricultural production is dependent on the consumption of fossil fuels (Taskin and Vardar, 2016). The use of energy in agriculture has increased due to the increasing human population, the limited supply of arable land and the will to improve the standard of living (Banaeian et al., 2010). Agriculture is an energy user and energy supplier (Alam et al., 2005). From the sowing- 
planting processes to the harvest-blending operations, direct energy is needed (Singh, 2007). Indirect energy is needed in the process from sowing to harvesting and transportation of products (Ozkan et al., 2004a). Yield, annual production, energy consumption, investments and costs are very high in greenhouses (Heidari and Omid, 2011). Inputs such as electricity, machinery, seeds, chemical fertilizers constitute a significant part of the inputs in the tomato production system (Hatirli et al., 2006). On the other hand, efficient use of energy contributes to increased production, profitability and competitiveness (Singh et al., 2002). Thus, sustainability in agriculture can be achieved in rural life (Park and Seaton, 1996). By using energy efficient in agriculture and by saving fossil fuels, air pollution can be reduced (Pervanchon et al., 2002). More efficient use of energy can be achieved so that the same level of development can be achieved with less energy use and less emissions (Ozturk et al., 2018). Using energy efficiently is very important for the terms of sustainability and the reduction of emissions of greenhouse gases (Alluvione et al., 2011). Energy used in agriculture is $17 \%$ of the world's energy (Mohammadi and Omid, 2010). The financial and technical analysis of the tomato production system is called the energy budget (Canakci and Akınc1, 2006). In terms of energy input-output relations, seed bed preparation, fertilizer quantity, soil cultivation processes and productivity etc. subjects are looked at (Mandal et al., 2002). In terms of production efficiency, input-output energy analysis is used (Alluvione et al., 2011). Production efficiency can be increased by reducing energy inputs. In the energy consumption in agriculture, mechanization is important (Ozkan et al., 2004b). The efficient use of energy provides sustainability (Dalgaard et al., 2001). In the world; there are important researches had done about field crops, fruits and the use of energy for vegetables. Energy inputs and outputs of apricot cultivation were examined (Gezer et al., 2003). Many researchers; soybean, corn and wheat in Italy (Sartori et al., 2005), tomatoes and tomato paste in Turkey (Esengün et al., 2007), lettuce in Colombia, radishes and spinach (Bojaca and Schrevens, 2010), rice in Malaysia (Bockari et al., 2005), kiwi in Iran production (Mohammadi et al., 2010), apple (Rafiee et al., 2010), onion and coriander Pennsylvania in the USA (Moore, 2010), the productivity of crops such as sugar cane production in Morocco (Mrini et al., 2001) has made energy issues and economic analysis. Work efficiency and alternative energy consumption in tomato production were analyzed (Onal and Tozan, 1986). Detailed energy usability surveys were conducted (Y1lmaz et al., 2005). Greenhouse energy and cost analysis were carried out in the Serik district of Antalya for the production of grapes in open-field and greenhouses (Ozkan et al., 2007). Some studies have been carried out on the use of energy in peach production in Tokat province (Goktolga et al., 2006). Economic analysis of the input energy requirements and costs are made in tomato production in Turkey (Cetin and Vardar, 2008).

The objectives of this study are; determine the effectiveness of tomato production systems, energy utilization rates, energy output-input ratio, cost/benefit ratio, energy inputs optimization of energy use efficiency and to determine the economic analysis. Thus in Mersin, greenhouse tomatoes and open-field tomato production systems will be compared.

\section{Materials and methods}

In this study, data were collected from 126 producers in open-fields and greenhouses in Mersin. In the Mediterranean city of Mersin, located south of Turkey. $36^{\circ} 48^{\prime}$ north 
latitude and $34^{\circ} 38^{\prime}$ east longitude. The average annual temperature is approximately 19.2 ${ }^{\circ} \mathrm{C}$ and the total annual rainfall is $592.1 \mathrm{~mm}$. Approximately $94 \%$ rainfall falls from October to May (TSMS, 2017). The total number of registered farmers in Mersin, in 2016 is 35039 (MAF, 2016). Data on the production of tomatoes collected by face-to-face survey from growers are belong to 2016 production period. in the province of Mersin, 941.232 tons of tomatoes were obtained from 91.211 decares of field. Sample farms were randomly selected from the study area by using a random sampling technique. However, it should be taken into account the factor in which variability can be observed in basic datasets. The sample size was calculated using the Neyman method (Eq. 1) (Yamane, 1967).

$$
\mathrm{n}=\frac{\mathrm{N} \times \mathrm{S}^{2}}{(\mathrm{~N}-1) \mathrm{S}^{2} x+S^{2}}
$$

For this equation; $\mathrm{n}$ is the required sample size, $\mathrm{N}$ population volume, $\mathrm{S}$ standard deviation, Sx standard deviation of the sample average $(\mathrm{Sx}=\mathrm{d} / \mathrm{z})$, $\mathrm{z}$ reliability coefficient, $\mathrm{d}$ is based on the allowable error equation of the sample size. For open-field and greenhouse tomato cultivation, the number of samples examined was 112 and 14 (126) respectively. The permissible error (d) was defined as 5\%, and for the 95\% reliability (z), 126 sampling sizes were calculated. Firstly, the most common production systems for each product were identified, and then all inputs and outputs from the systems were identified and digitized, and then converted to energy units. By adding partial energies to total energies (ha) per production unit; energy inputs include human labor, diesel fuel, machinery, farm manure, irrigation, nitrogenous, phosphorus and potassium chemical fertilizers. In order to estimate the energy in $\mathrm{MJ} / \mathrm{ha}$ and to find the amount of inputs in terms of efficiency values by the energy analysis of the tomato, the equivalents in Table 1 are used.

Table 1. Energy equivalents for different inputs and outputs in agricultural production

\begin{tabular}{|c|c|c|c|}
\hline Particulars & Unit & $\begin{array}{c}\text { Energy equivalent } \\
\left(\text { MJ unit }^{-1}\right)\end{array}$ & Reference \\
\hline $\begin{array}{l}\text { A. Inputs } \\
\text { 1. Human labor } \\
\text { 2. Machinery } \\
\text { 3. Diesel fuel } \\
\text { 4. Chemical fertilizers } \\
\text { (a) Nitrogen } \\
\text { (b) Phosphate } \\
\text { (c) Potassium } \\
\text { (d) Sulfur } \\
\text { (e) Zinc } \\
\text { (f) Mixed micronutrients } \\
\text { 5. Chemicals } \\
\text { (a) Herbicides } \\
\text { (c) Pesticides } \\
\text { (d) Fungicides } \\
\text { 6. Cattle manure } \\
\text { 7. Electricity } \\
\text { 8. Water for irrigation } \\
\text { 9. Seeds } \\
\text { B. Outputs } \\
\text { 1. Fruit yield }\end{array}$ & $\begin{array}{c}\mathrm{h} \\
\mathrm{h} \\
\mathrm{l} \\
\mathrm{kg} \\
\mathrm{kg} \\
\mathrm{kg} \\
\mathrm{kg} \\
\mathrm{kg} \\
\mathrm{kg} \text { or } 1 \\
\mathrm{~kg} \text { or } 1\end{array}$ & $\begin{array}{c}1.96 \\
64.80 \\
47.80 \\
\\
66.14 \\
11.10 \\
11.15 \\
1.12 \\
8.40 \\
120.00 \\
\\
238.30 \\
101.20 \\
216.00 \\
0.30 \\
11.93 \\
1.02 \\
1.00 \\
0.80\end{array}$ & $\begin{array}{c}\text { Mohammadi et al., } 2008 \\
\text { Singh et al., 2002 } \\
\text { Canakc1 and Akınc1, } 2006 \\
\text { Mohammadi et al., } 2008 \\
\text { Mani et al., 2007 } \\
\text { Kousar et al., 2006; Sartori et al., } 2005 \\
\text { Mohammadi et al., } 2008 \\
\text { Mohammadi et al., } 2008 \\
\text { Alam et al., 2005 } \\
\text { Esengun et al.,2007 Erdal et al., } 2007 \\
\text { Esengun et al., 2007 } \\
\text { Esengun et al., 2007 } \\
\text { Mohammadi et al., } 2008 \\
\text { Mani et al., 2007 } \\
\text { Rafiee et al., } 2010 \\
\text { Esengun et al., } 2007 \\
\text { Taki et al., 2012 }\end{array}$ \\
\hline
\end{tabular}


Energy use efficiency (Eq. 2), energy productivity (Eq. 3), specific energy (Eq. 4), energy intensiveness (Eq. 5) and net energy (Eq. 6) were calculated (Banaeian et al., 2010; Ghorbani et al., 2011).

$$
\begin{gathered}
\text { Energy use efficiency }=\frac{\text { Energy output }\left(M J h a^{-1}\right)}{\operatorname{Energy~input}\left(M J h a^{-1}\right)} \\
\text { Energy produvtivity }=\frac{\operatorname{Crops} \text { output }\left(K g h a^{-1}\right)}{\operatorname{Energy~input}\left(M J h a^{-1}\right)} \\
\text { Specific energy }=\frac{\text { Energy inpute }\left(M J h a^{-1}\right)}{\operatorname{Crops~output}\left(t \cdot h a^{-1}\right)} \\
\text { Energyintensiveness }=\frac{\operatorname{Energy~inpute~}\left(M J h a^{-1}\right)}{\operatorname{Cost} \text { of cultivation }\left(\$ h a^{-1}\right)} \\
\text { Net energy }=\left[\text { Energy output }\left(M J h a^{-1}\right)-\text { Energy input }\left(M J h a^{-1}\right)\right]
\end{gathered}
$$

The energy equivalents of the inputs are mega joule (MJ) per unit. In particularly this calculated ratio was used to express energy deficiency with input fossil fuel energy and output food ratio. The increase in the rate of crop production indicates improvement. It is possible to determine the energy efficiency trends of agricultural production by evaluating energy efficiency rates. Total value of production (Eq. 7), Gross return (Eq. 8), Net return (Eq. 9), Total cost of production (Eq. 10), Benefit to cost ratio (Eq. 11) and Productivity (Eq. 12) (Economic analysis of tomato cultivation) were investigated (Zangeneh et al., 2010):

$$
\begin{aligned}
& \text { Total value of production }=\text { tomato yield }\left(\mathrm{kg} \mathrm{ha}^{-1}\right) \times \text { tomato price }\left(\$ \mathrm{~kg}^{-1}\right) \\
& \text { Gross return }=\text { total value of production }\left(\$ \mathrm{ha}^{-1}\right)-\text { variable cost of production }\left(\$ \mathrm{ha}^{-1}\right) \\
& \text { Net return }=\text { total value of production }\left(\$ \mathrm{ha}^{-1}\right) \text {-total cost of production }\left(\$ \mathrm{ha}^{-1}\right) \\
& \text { Total cost of production }=\text { variable cost of production }\left(\$ \mathrm{ha}^{-1}\right)+\text { fixed cost of production }\left(\$ \mathrm{ha}^{-1}\right) \\
& \text { Benefit to cost ratio }=\text { total value of production }\left(\$ \mathrm{ha}^{-1}\right) / \text { total cost of production }\left(\$ \mathrm{ha}^{-1}\right) \\
& \text { Productivity }=\text { tomato yield }\left(\mathrm{kg} \mathrm{ha}^{-1}\right) / \text { total cost of production }\left(\$ \mathrm{ha}^{-1}\right)
\end{aligned}
$$

\section{Results}

\section{Energy input-output relationship in open-field and greenhouse tomato production system}

In tomato production systems, per hectare in open-fields and greenhouses, 1088.25 and $2347.82 \mathrm{~h}$ of human labor respectively and showed that 32.44 and $98.65 \mathrm{~h}$ machine power 
is required. The total energy used in production in open fields and green houses is 62862.93 and $183866.38 \mathrm{MJ} \mathrm{ha}^{-1}$ (Table 2). It is the electricity sector which has the highest energy consumption in tomato production system in open-fields $(32.89 \%)$, followed by nitrogen $(22.08 \%)$, irrigation $(13.55 \%)$ and diesel fuel $(12.66 \%)$ (Table 2) If the highest energy consumption in the tomato production system in greenhouses is diesel fuel $(60.90 \%$ of total energy input), followed by electricity $(14.68 \%$ ) and micro nutrients (fertilizer, $11.34 \%$ ) (Table 2). For tomato production systems, the average fruit yield in open fields and greenhouses were $147854 \mathrm{~kg} \mathrm{ha}^{-1}$ with 52429.8 respectively, while the straw yield were 2789.21 and $8744.37 \mathrm{~kg} \mathrm{ha}^{-1}$. While total energy output per hectare was $62862.93 \mathrm{MJ}$ in open fields and $183866.38 \mathrm{MJ}$ in greenhouses. The input-output energy ratio in open fields and greenhouse systems is 1.12 and 0.75 , respectively. The energy use efficiency in the open-field was nearly 1.49 times more than the greenhouse system due to the use of more input energy than the greenhouse system.

Table 2. Energy input-output relationship in openfield and greenhouse tomato production system

\begin{tabular}{|c|c|c|c|c|c|c|c|c|}
\hline \multirow[t]{2}{*}{ Energy inputs } & \multicolumn{2}{|c|}{$\begin{array}{l}\text { Quantity per unit } \\
\text { area } \\
\text { (ha) }\end{array}$} & \multicolumn{2}{|c|}{$\begin{array}{c}\begin{array}{c}\text { Energy } \\
\text { equivalent } \\
\left.\text { (MJ unit }^{-1}\right)\end{array} \\
\end{array}$} & \multicolumn{2}{|c|}{$\begin{array}{c}\text { Total energy } \\
\text { equivalent } \\
\text { (MJ) }\end{array}$} & \multicolumn{2}{|c|}{$\begin{array}{c}\text { Percentage of } \\
\text { total energy } \\
\text { input }(\%)\end{array}$} \\
\hline & $\begin{array}{c}\text { Open } \\
\text { field }\end{array}$ & $\begin{array}{l}\text { Green } \\
\text { house }\end{array}$ & $\begin{array}{c}\text { Open } \\
\text { field }\end{array}$ & $\begin{array}{l}\text { Green } \\
\text { house }\end{array}$ & $\begin{array}{l}\text { Open } \\
\text { field }\end{array}$ & $\begin{array}{l}\text { Green } \\
\text { house }\end{array}$ & $\begin{array}{c}\text { Open } \\
\text { field }\end{array}$ & $\begin{array}{l}\text { Green } \\
\text { house }\end{array}$ \\
\hline Human labor (h) & 1088.25 & 2347.82 & 1.96 & 1.96 & 2132.97 & 4601.73 & 3.80 & 1.88 \\
\hline Machinery (h) & 32.44 & 98.65 & 64.80 & 64.80 & 2102.11 & 6392.52 & 3.75 & 2.61 \\
\hline Diesel fuel (l) & 148.64 & 3124.57 & 47.80 & 47.80 & 7104.99 & 149354.45 & 12.66 & 60.90 \\
\hline Nitrogen $(\mathrm{kg})$ & 187.39 & 121.84 & 66.14 & 66.14 & 12393.97 & 8058.50 & 22.08 & 3.29 \\
\hline Phosphate (kg) & 96.27 & 73.15 & 11.10 & 11.10 & 1068.60 & 811.97 & 1.90 & 0.33 \\
\hline Potassium (kg) & 34.86 & & 11.15 & & 388.69 & 0.00 & 0.69 & 0.00 \\
\hline Sulphur (kg) & & 317.52 & & 1.12 & 0.00 & 355.62 & 0.00 & 0.15 \\
\hline Cattle manure (kg) & 11207.23 & 10621.46 & 0.30 & 0.30 & 3362.17 & 3186.44 & 5.99 & 1.30 \\
\hline Micro nutrients (kg or l) & 3.89 & 231.71 & 120.00 & 120.00 & 466.80 & 27805.20 & 0.83 & 11.34 \\
\hline Herbicides (kg or $\mathrm{l})$ & 1.91 & 0 & 238.30 & 238.30 & 455.15 & 0.00 & 0.81 & 0.00 \\
\hline Pesticides (1) & 1.63 & 4.43 & 101.20 & 101.20 & 164.96 & 448.32 & 0.29 & 0.18 \\
\hline Fungicide (kg or l) & 1.94 & 16.25 & 216.00 & 216.00 & 419.04 & 3510.00 & 0.75 & 1.43 \\
\hline Electricity $(\mathrm{kWh})$ & 1547.36 & 3018 & 11.93 & 11.93 & 18460.00 & 36004.74 & 32.89 & 14.68 \\
\hline Water for irrigation $\left(\mathrm{m}^{3}\right)$ & 7458.28 & 4624.54 & 1.02 & 1.02 & 7607.45 & 4717.03 & 13.55 & 1.92 \\
\hline Seeds (kg) & 0.87 & 0.28 & 1.00 & 1.00 & 0.87 & 0.28 & 0.00 & 0.00 \\
\hline Total energy input (MJ) & & & & & 56127.77 & 245246.78 & 100.00 & 100.00 \\
\hline \multicolumn{9}{|l|}{ Outputs } \\
\hline Fruit yield (kg) & 52429.8 & 147854.5 & 0.80 & 0.80 & 41943.86 & 118283.61 & 66.72 & 68.09 \\
\hline Straw yield $(\mathrm{kg})$ & 2789.21 & 8744.37 & 7.50 & 7.50 & 20919.08 & 65582.78 & 31.91 & 31.91 \\
\hline Total energy output (MJ) & & & & & 62862.93 & 183866.38 & & \\
\hline Energy efficiency & & & & & 1.12 & 0.75 & & \\
\hline
\end{tabular}

\section{Efficiency and specific energy in open-field and greenhouse systems}

Energy use efficiency is 1.12 in open-field and 0.75 in greenhouse tomato production systems. The energy intensiveness was calculated as 14.61 in open-field and $3.79 \mathrm{MJ}^{-1}$ in greenhouse systems. The average energy productivity of the open-field and greenhouse is 0.93 and $0.60 \mathrm{~kg} \mathrm{MJ}^{-1}$, respectively. Specific energy is 1.07 and $1.66 \mathrm{MJ}$ 
$\mathrm{kg}^{-1}$ in the open-field and in the greenhouse, respectively. Net energy is 6735.16 and 61380.40 $\mathrm{MJ} \mathrm{ha}^{-1}$ in open-field and greenhouse respectively (Table 3).

Table 3. Tomato production energy indices in open field and greenhouse systems

\begin{tabular}{c|c|c|c}
\hline Items & Unit & Open field & Greenhouse \\
\hline Energy input & $\mathrm{MJ} \mathrm{ha}^{-1}$ & 56127.77 & 245246.78 \\
Energy output & $\mathrm{MJ} \mathrm{ha}^{-1}$ & 62862.93 & 183866.38 \\
Energy use efficiency & - & 1.12 & 0.75 \\
Energy intensiveness & $\mathrm{MJ} \mathrm{\$}^{-1}$ & 14.61 & 3.79 \\
Specific energy & $\mathrm{MJ} \mathrm{kg}^{-1}$ & 1.07 & 1.66 \\
Energy productivity & $\mathrm{kg} \mathrm{MJ}^{-1}$ & 0.93 & 0.60 \\
Net energy & $\mathrm{MJ} \mathrm{ha}^{-1}$ & 6735.16 & -61380.40 \\
\hline
\end{tabular}

\section{Relationship between economic indices and analysis in tomato production system in open-field and greenhouse}

The production cost of our two works and our gross product can be seen at Table 4. In open-field and greenhouse tomato production systems, the gross production value is 14680.35 and $93148.34 \$ \mathrm{ha}^{-1}$. The tomato production and stability in the open-field was 3925.23 and $2390.94 \$ \mathrm{ha}^{-1}$, greenhouse facilities 15977.42 and $14486.52 \$ \mathrm{ha}^{-1}$. The production amount per hectare $\left(6316.16 \$ \mathrm{ha}^{-1}\right)$ in the open-field is lower than the greenhouse system $\left(30463.94 \$ \mathrm{ha}^{-1}\right)$. Total production amount in the greenhouse system is $79.27 \%$ higher than the open-field system. The gross return and net return (10755.12 and 8364.19 $\$ \mathrm{ha}^{-1}$ ) available in open-field production is very low from the greenhouse production system (77170.92 and 62684.40 $\left.\$ \mathrm{ha}^{-1}\right)$. The gross and net return in the open field system is 7.2 and 7.5 times lower. In greenhouses (3.06), the benefit cost ratio is higher than the open-field system (2.32). Productivity is expressed in 1 US\$, this means how much product we can produce with 1 US dollar. This study efficiency is 8.30 and $4.85 \mathrm{~kg}^{-1}$ for open-field and greenhouse systems.

Table 4. Economic indices of tomato production in open space and greenhouse systems and relationship between analysis

\begin{tabular}{c|c|c}
\hline Cost and return components & Open field (value) & Greenhouse (value) \\
\hline Fruit yield $\left(\mathrm{kg} \mathrm{ha}^{-1}\right)$ & 52429.82 & 147854.51 \\
Sale price $\left(\$ \mathrm{~kg}^{-1}\right)$ & 0.28 & 0.63 \\
Gross value of production $\left(\$ \mathrm{ha}^{-1}\right)$ & 14680.35 & 93148.34 \\
Variable cost of production $\left(\$ \mathrm{ha}^{-1}\right)$ & 3925.23 & 15977.42 \\
Fixed cost of production $\left(\$ \mathrm{ha}^{-1}\right)$ & 2390.94 & 14486.52 \\
Total cost of production $\left(\$ \mathrm{ha}^{-1}\right)$ & 6316.16 & 30463.94 \\
Total cost of production $\left(\$ \mathrm{~kg}^{-1}\right)$ & 0.12 & 0.21 \\
Total cost production $\left(\$ \mathrm{MJ}^{-1}\right)$ & 0.06 & 0.09 \\
Gross return $(\$ \mathrm{ha}-1)$ & 10755.12 & 77170.92 \\
Gross return $\left(\$ \mathrm{~kg}^{-1}\right)$ & 0.21 & 0.52 \\
Gross return $\left(\$ \mathrm{MJ}^{-1}\right)$ & 0.10 & 0.22 \\
Net return $\left(\$ \mathrm{ha}^{-1}\right)$ & 8364.19 & 62684.40 \\
Net return $\left(\$ \mathrm{~kg}^{-1}\right)$ & 0.16 & 0.42 \\
Net return $\left(\$ \mathrm{MJ}^{-1}\right)$ & 0.08 & 0.18 \\
Benefit to cost ratio & 2.32 & 3.06 \\
Productivity $\left(\mathrm{kg} \$^{-1}\right)$ & 8.30 & 4.85 \\
\hline
\end{tabular}




\section{Discussion}

In tomato production systems, the total energy input (56127.77 $\left.\mathrm{MJ} \mathrm{ha}^{-1}\right)$ used in the open-field has shown that it is approximately 4.37 times lower than the greenhouse production system (245246.78 $\mathrm{MJ} \mathrm{ha}^{-1}$ ). Diesel fuel consumption in the production of tomatoes in greenhouses is very high. In addition, energy consumption in greenhouse production systems is higher than the open-field production system. But, the energy use rate is lower (Cetin and Vardar, 2008). In addition, tomato yield in the open field $\left(52429.82 \mathrm{~kg} \mathrm{ha}^{-1}\right)$ is 2.82 times lower than the greenhouse system $\left(147854.51 \mathrm{~kg} \mathrm{ha}^{-1}\right)$ (Özkan et al., 2004b). Energy output-input ratio is higher in open-field (1.12) than in greenhouse systems $(0.75)$.

\section{Conclusions}

Reducing the share of fertilizers and diesel fuel may increase energy efficiency. Net energy is -61380.40 and 6735.16 $\mathrm{MJ} \mathrm{ha}^{-1}$ in greenhouse systems and outdoor field. A negative value of the energy gain in the greenhouse is due to the heating technology used for heating diesel engines at high temperatures, such as low heating technology (Banaeian et al., 2010). In the open field, respectively, 10755.12 \$, 8364.19 \$ and 2.32; The gross, net return and benefit cost ratio is lower than the greenhouse tomato production system. Total production cost of greenhouse is higher than open-field due to heavy fuel usage. The high price of greenhouse tomatoes is owing to the lack of tomatoes in autumn and winter. Effective use of inputs contributes to economic profitability and competitiveness, while increasing productivity (Singh et al., 2002). The results show that water for diesel fuel, irrigation, fertilization, machinery and electrical energies is the major part of the energy inputs used in tomato production systems. In terms of energy efficiency, the tomato production system in the open-field is 1.49 times higher than the greenhouse system. This leads to an increase towards higher sustainability. In addition, the most effective factors affecting the efficiency of energy use in greenhouse and open-field systems are diesel fuel and nitrogen fertilizer inputs. Therefore, reducing the consumption of these inputs may increase the efficiency of energy use in tomato production systems in Mersin province.

\section{REFERENCES}

[1] Abak, K. (2018): Tomatoes yesterday in Turkey, today and tomorrow. - Lefke European University Faculty of Agricultural Sciences, Gemikonağ - Lefke, Mersin, TTOB Journal 17: 8-9. www.turktob.org.tr/dergi/makaleler/dergi17/TTOB_Dergi17WEB-8_13.pdf.

[2] Alam, M. S., Alam, M. R., Islam, K. K. (2005): Energy flow in agriculture: Bangladesh. - American Journal of Environmental Sciences 1(3): 213-220.

[3] Alluvione, F., Moretti, B., Sacco, D., Grignani, C. (2011): EUE (energy use efficiency) of cropping systems for a sustainable agriculture. - Energy 36: 4468-4481.

[4] Anonymous (2017): https://www.mersinportal.com/mersin/mersinde-940-bin-tondomates-uretiliyor-h39341.html.

[5] Banaeian, N., Omid, M., Ahmadi, H. (2010): Energy and economic analysis of greenhouse strawberry production in Tehran province of Iran. - Energy Conversion and Management 52(2): 1020-1025 
[6] Bockari Gevao, S. M., Wan Ishak, W. I., Azmi, Y., Chan, C. W. (2005): Analysis of energy consumption in lowland rice-based cropping system of Malaysia. - Sci Technol 27(4): 819-826.

[7] Bojaca, C. R., Schrevens, E. (2010): Energy assessment of peri-urban horticulture and its uncertainty: case study for Bogota, Colombia. - Energy 35: 2109-2118.

[8] Canakci, M., Akinci, I. (2006): Energy use pattern analyses of greenhouse vegetable production. - Energy 31: 1243-1256. 31(8-9): 1243-56.

[9] Cetin, B., Vardar, A. (2008): An economic analysis of energy requirements and input costs for tomato production in Turkey. - Renewable Energy 33: 428-433.

[10] Dalgaard, T., Halberg, N., Porter, J. R. (2001): A model for fossil energy use in Danish agriculture used to compare organic and conventional farming. - Agric. Ecosyst. Environ. 87: 51-65.

[11] Erdal, G., Esengun, K., Guduz, O. (2007): Energy use and economic analysis of sugar beet production in Tokat province of Turkey. - Energy 32: 34-41.

[12] Esengun, K., Gunduz, O., Erdal, G. (2007): Input-output energy analysis in dry apricot production of Turkey. - Energy Conversion and Management 48(2): 592-598.

[13] FAO (2013): Faostat Agricultural Database. - www.faostat.org. Accessed: 17.02.2015.

[14] Gezer, I., Acaroglu, M., Hacseferogullari, H. (2003): Use of energy and labour in apricot agriculture in Turkey. - Biomass Bioenerg 24: 215-9.

[15] Ghorbani, R., Mondani, F., Amirmoradi, S., Feizi, H., Khorramdel, S., Teimouri, M., Sanjani, S., Anvarkhah, S., Aghel, H. (2011): A case study of energy use and economical analysis of irrigated and dryland wheat production systems. - Appl Energy 88: 283-288.

[16] Goktolga, Z. G., Gozener, B., Karkacier, O. (2006): Energy use in peach production: Case of Tokat province. - GOU. J. Agric. Faculty 23(2): 39-44.

[17] Hatirli, S. A., Ozkan, B., Fert, C. (2006): Energy inputs and crop yield relationship in greenhouse tomato production. - Renewable Energy 31: 427-438.

[18] Heidari, M. D., Omid, M. (2011): Energy use patterns and econometric models of major greenhouse vegetable productions in Iran. - Energy 36(1): 220-225.

[19] Kinet, J.M., Peet , M.M. (1997): Tomato : In Wien , H.C.(Ed), The Physiology of Vegetable Crops. CAB, International. New York, pp.207-258.

[20] Kousar, R., Makhdum, S. A., Yagoob, S., Saghir, A. (2006): Economics of energy use in cotton production on small farms in district Sahiwal, Punjab, Pakistan. - J Agric Social Sci 2(4): 219-221.

[21] MAF (2016): Republic of Turkey Ministry of Agriculture and Forestry. https://www.tarimorman.gov.tr/SGB/TARYAT/Belgeler/il_yatirim_rehberleri/mersin.pdf

[22] Mandal, K. G., Saha, K. P., Gosh, P. L., Hati, K. M., Bandyopadhyay, K. K. (2002): Bioenergy and economic analyses of soybean based crop production systems in central India. - Biomass Bioenerg 23: 337-45.

[23] Mani, I., Kumar, P., Panwar, J. S., Kant, K. (2007): Variation in energy consumption in production of wheat-maize with varying altitudes in hilly regions of Himachal Pradesh, India. - Energy 32: 2336-2339.

[24] Mohammadi, A., Omid, M. (2010): Economical analysis and relation between energy inputs and yield of greenhouse cucumber production in Iran. - Appl Energy 87: 191-196.

[25] Mohammadi, A., Tabatabaeefar, A., Shahin, S., Rafiee, S., Keyhani, A. (2008): Energy use and economical analysis of potato production in Iran, a case study: Ardabil province. - Energy Conver Manage 49: 3566-3570.

[26] Mohammadi, A., Rafiee, S., Mohtasebi, S., Rafiee, H. (2010): Energy inputs-yield relationship and cost analysis of kiwifruit production in Iran. - Renew Energy 35: 10711075.

[27] Moore, S. R. (2010): Energy efficiency in small-scale biointensive organic onion production in Pennsylvania, USA. - Renewable Agriculture and Food Systems 25: 181188. 
[28] Mrini, M., Senhaji, F., Pimentel, D. (2001): Energy analysis of sugarcane production in Morocco. - Environ Dev Sustain 3: 109-126.

[29] Onal, I., Tozan, M. (1986): Energy budget and work requirements of the alternative production systems in the processing tomato production. - In: 10th National Agricultural Mechanization Congress, Adana, Turkey, May 5-7, pp. 216-28 [in Turkish].

[30] Ozkan, B., Kurklu, A., Akcaoz, H. (2004a): An input-output energy analysis in greenhouse vegetable production: a case study for Antalya region of Turkey. - Biomass Bioenergy 26(1): 189-195.

[31] Ozkan, B., Akcaoz, H., Fert, C. (2004b): Energy input-output analysis in Turkish agriculture. - Renew Energy 29: 39-51.

[32] Ozkan B., Fert C., Karadeniz, C. F. (2007): Energy and cost analysis for greenhouse and open field grape production. - Energy 32: 1500-04.

[33] Ozturk, H. H., Kücukerdem, K., Mutlu, N., Gozubuyuk, Z., Atay, U. (2018): Sustainability indicators for energy use and environmental impacts in agricultural production. - Journal of Agricultural Machinery Science 14(3): 199-204.

[34] Park, J., Seaton, R. A. F. (1996): Integrative research and sustainable agriculture. Agricultural Systems 50(1): 81-100.

[35] Pervanchon, F., Bocstaller, C., Girardin, P. (2002): Assessment of energy use in arable farming systems by means of an agro-ecological indicator: the energy indicator. - Agric. Syst. 72: 149-172.

[36] Rafiee, S., Mousavi, S. H., Mohammadi, A. (2010): Modeling and sensitivity analysis of energy inputs for apple production in Iran. - Energy 35: 3301-3306.

[37] Sartori, L., Basso, B., Bertocco, M., Oliviero, G. (2005): Energy use and economic evaluation of a three year crop rotation for conservation and organic farming in NE Italy. - Biosyst. Eng. 91(2): 245-256.

[38] Singh, H., Mishra, D., Nahar, N. M. (2002): Energy use pattern in production agriculture of a typical village in arid zone India - Part I. - Energy Convers Manage 43(16): 22752286.

[39] Singh, H., Singh, A. K., Kushwaha, H. L., Singh, A. (2007): Energy consumption pattern of wheat production in India. - Energy 32: 1848-1854.

[40] Taki, M., Ajabshirchi, Y., Mobtaker, H. G., Abdi, R. (2012): Energy consumption, inputoutput relationship and cost analysis for greenhouse productions in Esfahan Province of Iran. - American Journal of Experimental Agriculture 2(3): 485-501.

[41] Taskın, O., Vardar, A. (2016): Use of some renewable energy resources in agricultural production. - Journal of Agricultural Faculty of Uludag University 30(1): 179-184.

[42] TSMS (2017): Turkish State Meteorological Service. https://www.mgm.gov.tr/?il=Mersin.

[43] Turemiş, N. (2015): Greenhouse Growing in Turkey. - http://bahcebitkileri.cu. edu.tr/upload/nturemis/turkiyeortualti.pdf.

[44] Yamane, T. (1967): Elementary Sampling Theory. - Prentice Hall, Englewood Cliffs, NJ.

[45] Yanmaz, R., Duman, İ., Yaralı, F., Demir, K., Sarıkamış, G., Sarı, N., Balkaya, A., Kaymak, H. Ç., Akan, S., Özalp, R. (2015): Changes in vegetable production and new explorations. - Chamber of Agricultural Engineers of TMMOB VIII. Technical Congress Proceedings, pp. 579-605.

[46] Yilmaz, I., Akcaoz, H., Ozkan, B. (2005): An analysis of energy uses and input-output costs for cotton production in Turkey. - Renewable Energy 30(1): 145-55.

[47] Zangeneh, M., Omid, M., Akram, A. (2010): Comparative study on energy use and cost analysis of potato production under different farming technologies in Hamadan province of Iran. - Energy 35: 2927-2933. 